\title{
A NEW APPROACH TO THE ETYMOLOGY OF THE OLD NORSE NAME OF KIEV - KØNUGARĐR (the thesis of Elsa Melin on the Name given to Kiev in the Icelandic Sagas, with an Excursus on Kind in Place-Names)*
}

One of the most interesting and intriguing linguistic problems of the early Middle Ages in Rus' (Russia) is the problem of how the Varangians and Eastern Slavs communicated. How great were the competences of all sides of this interrelationship? Was there some oral usage in which those languages mixed, and what role was played by the translation from one language to another in those intercultural contacts?

As is known, there is not much evidence of this language interaction at our disposal. A most important place in the list of such evidence is taken by toponyms, and, to be more exact, how the Scandinavians named various geographical places of the East Europe. Among the most famous of these geographical names were the Varangian names of three cities situated along the Way from the Varangians to the Greeks («путь из варяг в греки»): Hólmgarðr = Novgorod (Новгород), Kønugarðr = Kiev (Киев), and Miklagarðr = Constantinople $\left(\mathrm{KoH}_{-}\right.$ стантинополь). No doubt the element -gardr was the first to attract attention of the scholars, for it united all the three toponyms and the Old Norse name of Rus' - Garðar or Garðaríki. Thus, the Norse-Slavonic linguistic interaction here was manifested in the most obvious way since the Slavonic grad, gorod (zpadr, zopodz) and Old Norse gardr, garðar are close to each other in etymology and phonetics yet differ semantically. In Scandinavian languages garðr was known to designate 'farmstead, estate, enclosure, yard'. Only in the place-names cited

${ }^{*}$ ) Abbreviation: CCRC - Полное собрание русских летописей [Complete Collection of Russian Chronicles]. T. 1-43 (Санкт-Петербург-Москва-Ленинград, 1841-2004). 
above did this element gardr acquired the "urban" coloring, which is intrinsic to the corresponding Slavonic words. ${ }^{1}$

While there is some agreement among the scholars concerning the element gardr, no less important for the problem of the VarangianSlavonic language contacts is the meaning of the first elements of our place-names Hólm-, Mikla- and Kønu- (Kænu-, Kiænu-, Kønu-). The origin of Constantinople's name Miklagardr seems obvious since the first element is simply an adjective mikill meaning 'big, great'. The meaning of the whole name is then 'Great city'. Discussion arises only on the base of various cultural-linguistic associations connected with this designation. With respect to Norse-Russian connections, here the fact should be mentioned that these Northern peoples did not use the autochthonous Greek name of the capital of the empire, but constructed their own names. Both those names, Miklagardr and Tsar'grad (Царьград), undoubtedly were meant to stress the special state of Constantinople among other towns of the world. It is significant that in the Scandinavian tradition, the first element could be, apparently, just omitted: in the early prose texts, the Byzantine capital was designated as Gardr, ${ }^{2}$ though the two-element name Miklagardr remained more popular in sagas.

The situation is much more complicated with the toponym Hólmgarðr which is used for Novgorod in the Old-Norse texts. While for Miklagardr only one, and a rather reliable, etymology exists, the first element of the place name Hólmgardr has at least two etymologi-

(1) For detail, see: В. Томсен, Начало русского государства, in: А. Ф. ИИтвИНА, Ф. Б. УСПЕнСКИЙ (сост.), Из истории русской культуры. Т. II. Кн. 1. Киевская и Московская Русь (Москва, 2002) 189; V. Thомsen, Samlede Afhandlinger 1. (København, 1919) 332; Е. А. РыдзевскАя, О названии Руси Garðaríki, in: ЕАDем, Древняя Русь и Скандинавия (IX-XIV вв.) (Москва, 1978) 143-150; Е. А. МЕльниковА, Восточноевропейские топонимы с корнем-garð в древнескандинавской письменности, Скандинавский сборник 22 (1977) 199-210; Т. Н. Джаксон, Austr í Görðит: Древнерусские топонимы в древнескандинавских источниках (Москва, 2001) 49-59; also cf.: F. В. UspensкIJ, Asgard, Midgard und Utgard in Kontext der altskandinavischen Toponymie zur Bezeichnung osteuropäischer Orte. Eine Etüde zur euhemeristischen Interpretation einiger mythologischen Objekte bei Snorri Sturluson, in: Das Wort (Berlin, 2000) 225-242; Ф. Б. УСпенСкИй, Скандинавы - Варяги - Русь: Историко-филологические очерки (Москва, 2002) 371-389.

(2) See: UspensкiJ, Asgard, Midgard...; Успенский, Скандинавы..., 290291 with references. 
cal versions. ${ }^{3}$ The element hólm- , on the one hand, is close to the Slavonic $x^{r} b \lambda \mathcal{M} b$ 'hill' and, on the other hand, some scholars see in this element the properly Scandinavian word hólmr 'island'. Thus, for the Old Norse name of Novgorod stands either a toponymic concept of the town on the island, or some phonetic assimilation to the autochthonous name. The latter may have arisen because the Slavonic toponym Holm $(X b \wedge \mathcal{M r})$ is mentioned in the chronicles as the designation of one of the Novgorod districts. ${ }^{4}$

Though it seems a paradox, from linguistic and historical viewpoints both explanations of the Old Norse Hólmgardr appear to be acceptable. The matter is complicated by the fact that even if the Slavonic

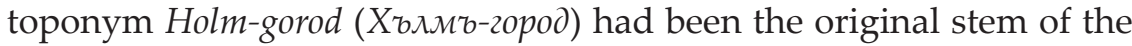
Old Norse place-name very early, its similarity to the Scandinavian lexeme hólmr 'island' would inevitably have been involved in the choice of the name, a process called "paronymic attraction." Moreover, the topographic peculiarities that Varangians coming to Novgorod faced would have justified the name based on its meaning in their language as well.

Anyway, the town on the bank of the Volkhov river since a rather early time has been called by the Slavonic name Novgorod (Новгород), while in the Old Norse sources it preserves its name Hólmgardr. Thus, two Scandinavian toponyms with the -garðr element give us visual examples of a cultural-linguistic model, in which there is no phonetic similarity between the initial elements of the local and foreign names of a town, though, nevertheless, they exist alongside with each other for several centuries. Indeed, Miklagarðr, Tsar'grad (Царьгpad) and Constantinople, Hólmgarðr and Novgorod (Hовzopod) are names partially similar in the word-forming principles, though having nothing in common from the viewpoint of the phonetics of their initial components.

Especially unclear are the semantics and origin of the Scandinavian name of "the mother of the towns of the Rus", Kønugardr = Kiev. By its phonetic image and inner structure, this Scandinavian word may be

(3) For a survey of the history of the problem, see: ДжАКсоН, Austr i Görðum..., 83-90.

(4) Previously, V. L. Yanin and M. H. Aleshkovsky advanced a hypothesis that Holm-gorod (Xbлиn-zopod, i.e. 'Hill-town') had been the original, most ancient name of one of the settlements that later formed Novgorod (see: В. А. Янин, М. Х. АлЕшковский, Происхождение Новгорода (К постановке проблемы), История СССР 2 (1971) 41). 
connected with the Old-Russian Kiev (Kblஈbr), but the connection is not close at all; therefore, at first sight both the hypotheses of the similar origins of these names and those considering them as independent seem equally possible.

For example, V. Thomsen once proposed a connection of the first element in the word Kønugarðr with the Old Norse kœna (kóna), meaning a certain kind of boat. Kønugarðr (Kœnugarðr), thus, appeared to mean for the Scandinavians a sort of 'town of boats'. ${ }^{5}$ However, the scholar used this etymological supposition with a question mark, considering it neither evident nor doubtless. Indeed, in the existing Old Norse texts the word kœna occurs but very rarely. As a matter of fact, just two cases of its usage are known, one of them being rather ambiguous. The word kœna figures in one of pula (versified list of poetical synonyms) of the Younger Edda where various terms signifying different vessels ${ }^{6}$ are given without indications of any characteristics of each of them. Thus, if we had had no second case of the usage of this word we would have called kœna an exotic poetical term.

As for the second case, it is very difficult for interpretation as it is. I mean the nickname of some noble Norwegian who lived rather late, in the second half of the $12^{\text {th }}$ century. In the sagas and poems by Pórbjörn Skakkaskáld he appears as Frírek Køna, ${ }^{7}$ however, the meaning of his nickname is interpreted differently by scholars. It is either connected with the boat, ${ }^{8}$ or with the adjective koenn 'skilful, clever'. ${ }^{9}$ A significant argument in favor of one of the interpretations of the nickname, and also of the estimation of the occurrence of the word kæna in the Old Norse in general, is the evidence of modern Icelandic,

(5) Seе: Томсен, Начало русского государства, 189; cf.: В. Hesselman, Kritiska småbidrag till fornislädsk ordhistoria, Göteborgs Högskolas Årsskrift 32.3 (1925) 105-111. This hypothesis is criticized, in particular, in the paper: G. Sснгамм, Die normannischen Namen für Kiev und Novgorod, Russia Mediævalis 5.1 (1984) 79; B. STRumiński, Linguistic Interrelations in Early Rus': Northmenn, Finns and East Slavs (Ninth to Eleventh Centuries) (Roma-Toronto, 1996) (Collana di Filologia e Letterature Slave, 2) 121-132.

(6) See: Finnur Jónsson, Den norsk-islandske Skjaldedigtning. B (Rettet tekst), Bd. I (København, 1973) 668.

(7) See, for example: Ibid., 516.

(8) See, for example: J. FrITZner, Ordbog over det gamle norske Sprog, Bd. 2 (Oslo, 1954) 386; cf.: Hesselman, Kritiska småbidrag..., 108.

(9) See: E. H. Lind, Norsk-Isländska Personbinamn från Medeltiden. Samlade och utgivna med Förklaringar (Uppsala, 1920-1921) 232. 
where the word kœna in the meaning of 'small boat, canoe' is reliably observed. ${ }^{10}$

It follows from the foregoing that $\mathrm{V}$. Thomsen's hypothesis does not imply any direct etymological connection between the Slavonic name Kiev (Kolєвъ) and the Scandinavian Kønugardr (Kœnugarðr).

In the alternative etymology, the name Kønugardr was related to Kijanov gorod (Киянов город) which occurs once in the bylinas. ${ }^{11}$ It was assumed that this form developed from a certain toponym *Kyjan(ov)gorod ( ${ }^{*} \operatorname{Kasн(ов)r-zopodrb)~that,~however,~was~not~found~in~any~source.~}$ In my opinion, the absence of this toponym in the texts is quite understandable. Indeed, the scholars (J. Mikkola, and later S. Rožniecki and V. Brim) assumed that the initial element Kijan-/ ${ }^{*}$ Kyjan$($ Киянь- / Кьянь-) "is the genetive case plural of Kijanin, Kyjanin, i.e.

(10) It is possible that some trace of these 'boat' semantics of the Old Norse name of Kiev can be found in the later Old Russian eponymic legend, where the chronicler had to refute the rumour about Kii, the founder of the city, being a boatman: "Some ignorant persons have claimed that Kii was a ferryman, for near Kiev there was at that time a ferry from the other side of the river, in consequence of which people used to say, "To Kii's ferry." Now, if Kii had been a mere ferryman, he would never have gone to Constantinople. He was then the chief of his kin, and it is related what great honour he received from the emperor when he went to visit him. On his homeward journey, he arrived at the Danube. The place pleased him, and he built a small town, wishing to dwell there with his kinfolk. But those who lived nearby would not grant him this privilege. Yet even now the dwellers by the Danube call this town Kievetz. When Kii retumed to Kiev, his native city, he ended his life there; and his brothers Shchek and Khoriv, as well as their sister Lybed, died there also" (CCCR, vol. I, col. 9-10; vol. II, col. 7-8). No doubt, the evidence from Constantine Porphyrogenitus repeatedly mentioned by scholars, which attests to Kiev as the place where one-tree boats were brought to, made by the Slavs for the Rus' (i.e. Scandinavians) (Constantine Porphyrogenitus, De administrando imperio (Washington, 1967) Ch. 9).

(11) See: J. J. МıккоцA, Om några ortnamn i Garðarike, ANF 19 (1907) 270-280; С. РожнецкИй, Из истории Киева и Днепра в былевом эпосе, Известия Отделения русского языка и словесности Российской академии наук 16.1 (1911) 28-63; S. RožNIECKI, Varaegiske minder $i$ den russiske heltedigtning (København, 1914) 283-284; Schramm, Die normannischen Namen..., 77-78; H. Trunte, Kyj - ein altrussischer Städtegründer?, Die Welt der Slawen 12 (1988) 13; cf. also: Thomsen, Samlede Afhandlinger, 314; J. DE VRIEs, Altnordisches etymologisches Wörterbuch (Leiden, 1977) 342. Of the recent papers, see: ДжАКCOH, Austr i Gördum..., 64-68 with references. In addition, see: StrumińsKI, Linguistic Interrelations in Early Rus'..., 121-132, where the author disagrees with this viewpoint. 
inhabitants of Kiev." ${ }^{12}$ According to S. Rožniecki, the toponym should be interpreted as 'the town of inhabitants of Kiev' («город киян»). ${ }^{13}$ It seems that this model of city naming including the genitive plural of the name of the city inhabitants plus a suffix meaning "town or "city" $(2 p a d v$, городъ) has no ground in the East Slavonic material. Neither in the Old-Russian texts nor in modern Russian could we find toponyms formed by this model. The reconstruction of a non-existent Slavonic place name ${ }^{*} \mathrm{Kyjan}(\mathrm{ov})$-gorod ( ${ }^{*}$ Кьяян(ов)r-zородъ) seems less convincing. As S. Rožniecki pointed out, the rare expression from bylinas was rather connected not with the city on the bank of the Dnepr, but with the popular etymology, the mythic or poetic theme of Okijan gorod («Окиян-город», lit. 'Ocean city').

Thus, the hypothesis implying that the Scandinavian Kønugardr from the very beginning had been derived from the phonetically similar Slavonic place-name seems less valid than the one implying the proper Scandinavian origin of this word. It should be taken in consideration, however, that these two hypotheses do not exclude each other. During the centuries of rather close Scandinavian-Russian contacts, a place-name that had been originally understood by the Varangians as 'town of boats', later could be interpreted as 'town of kijans (the inhabitants of Kiev)'. The original etymology of the word could have got mixed up rather early with the popular etymology; certainly, this popular etymology eclipsing the original meaning of the place-name would not be less interesting or informative for a historian of language and culture. Moreover, often the latest connotations acquired by a word during its existence are so expressive that the problems of the "right" etymology become not so important and often unsolvable in principle.

Nevertheless, the original Scandinavian name of Kiev is not so mysterious that ascertaining its etymology with a reasonable degree of certainty is hopeless. It is true that neither the Scandinavian nor the Slavonic language material gives us a clear and unquestionable explanation of Kønugardr. In other words, while we have a single, allsatisfying etymology of the place-name Miklagardr, and two equally valid ones for the Scandinavian name of Novgorod (Hólmgarðr), for

(12) See: В. А. Брим, Путь из варяг в греки, in: А. Ф. АитвинА, Ф. Б. УСПенСКИЙ (сост.), Из истории русской культурь. Т. ІІ. Кн. 1. Киевская и Московская Русь (Москва, 2002) 252.

(13) Seе: Рожнецкий, Из истории Киева и Днепра..., 50. 
Kønugardr, strictly speaking, there is no etymological explanation that could be fully exhaustive and convincing even for its supporters. But it may be possible to find some criteria which should be satisfied by any reconstruction of the genesis of the Scandinavian Kønugardr. In particular, when we advance this or that new solution of the problem based on linguistic grounds, the value of the hypothesis increases if we are able to adduce some independent historical or historical-cultural arguments in its favor.

In this respect, a quite recent paper by the Swedish researcher Elsa Melin is very interesting. ${ }^{14}$ Melin in her study of the etymology of Kønugardr, gives a new solution of the problem of the search for correspondences to the element $k ø n u-$ in the Scandinavian linguistic material quite different from those by V. Thomsen, J. Mikkola, E. A. Rydzevskaya, and other researchers. Melin refers the element kønu- to the Old Norse noun of feminine gender kinn, originating in turn from the Indo-European stem ${ }^{*}$ genw- / genu-. (As the author notes, the Old Norse word etymologically corresponds to the Greek

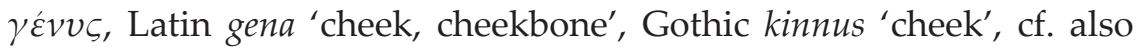
Old Indian hánu-, Avestian zānu- 'cheekbone', Old Irish gin 'mouth', Lithuanian žánda-s 'cheek, cheekbone', and Tocharian śanwem (Dualis) 'cheekbone'.) Of several concurrent spelling forms of the Old Norse place-name (Kenugarðr, Kœnugarðr, Kiænugarðr, Kænugarðr, Kiænugarðr, Kønugarðr) Melin choose Kønugarðr as the most appropriate to the phonetic image of the word in question in the epoch when the growing town acquired its Scandinavian name. Further, she explains how this phonetic image was formed.

Her reconstruction of the alternative way that resulted in $-i-$ instead of $-\varnothing$ - in the survived noun kinn in one of the elements of this place-name is rather complicated. ${ }^{15}$ Let us try, without going into de-

(14) See: E. Melin, Kønugardr, the Name given to Kiev in the Icelandic Sagas, with an Excursus on Kind in Place-Names, ANF 120 (2005) 55-68.

(15) The existence of two variants of the stem (kinn- and ken-) for the word "cheek, chin" is not surprising: as Prof. O. A. Smirnitskaya has observed (in an oral communication), the parts of the human body recognized as cosmogonic objects in the Old Germanic languages made a special group and could be varied in many ways. In particular, there were variations in the postvocal consonants which at the following stages of language development could determine this or that vocalism of the stem. The many-step character of Melin's reconstruction was much conditioned by the fact that she had to justify two stages of not quite usual evolutional changes that had occurred, in 
tail in her analysis of the phonetic transformations, to consider what consequences may be derived from the very idea of identity of the elements kønu- (from *ken-) and kinn.

The word kinn in the Old Norse sources may have the meaning 'cheek' and the meaning 'a slope of the mountain' or 'a hill'. This to the highest degree corresponds to the universal linguistic tendency to transfer names of parts of the body and face to elements of landscape. ${ }^{16}$ These metaphorical names are, so to say, readily "toponymized," that is, fixed to a certain locus and turned into its stable name. In Melin's paper Scandinavian material is referred to in which the place-names treat such anatomical elements in different ways. The next step of the researcher was a conclusion, quite right in my opinion, that the Scandinavian place-name containing the element kinn-is a cálque or, in any case, translation, of a certain Slavonic toponym.

As for Melin's opinion of the question as to which local place-name is reflected in the Old Norse Kønugardr, here, I believe, the researcher rejects a direct and easily proved solution and takes the way which is much more complicated and dubious. She assumes that the Scandinavian kinn 'the slope of a hill, cheek' contained in Kønugardr is the cálque of the place-name Kiev (Kbl€br) which in its turn was derived from the Slavonic *kij 'hill' reconstructed by the author ${ }^{17}$ (sic! must be ${ }^{*} k y j b$ or $\left.{ }^{*} k \bar{u} j\right)$.

First, the reconstruction of the meaning of Slavonic ${ }^{*} k i j$ (i. e. * $k y j b$ or ${ }^{*} k \bar{u} j$ ) is at least dubious. Apparently, the researcher's interpretation follows from the thesis of S. Rospond, who supposed that the Slavonic name of the town derived from the stem ${ }^{*} k \bar{u} j$ and believed it was connected with the Polish dialectal kujava 'sand hill'. ${ }^{18}$ Here too both the

her opinion, with the Indo European stem *genw - / genu- on the Scandinavian background. First, she had to explain in what way, alongside with kinn, the stem *ken appeared. In addition, the subsequent labial mutation (umlaut) of this hypothetic stem *ken also deserved further comment (the stem *ken led to the element $k ø n u-$ we are interested in). It should be noted that the linguistic concept by Melin requires accepting a number of theoretically probable but by far not doubtless assumptions and reconstructions. For detail, see: Melin, Kønugarðr, the Name given to Kiev..., 58-59.

(16) See: O. Rygh, Norske Gaardnavne 2 (Kristiania, 1898) 60; cf.: E. EKwALL, The Concise Oxford Dictionary of English Place-Names (Oxford, 1960) 105.

(17) See: Melin, Kønugardr, the Name given to Kiev..., 62.

(18) Seе: С. Роспонд, Значение древнерусской ономастики для истории (К этимологии топонима Киев), Вопросы языкознания 1 (1968) 
origin of the original stem and its semantics remain unclear. For example V. V. Ivanov and V. N. Toporov assume ${ }^{*} k \bar{u} j b$ to be a derivative of *kov- with the main meaning 'club, hammer, rod, warder' ${ }^{19}$ This interpretation of the Slavonic * $k \bar{u} j b$ comes close to the traditional etymology of this word including the meaning 'stick, rod, wooden hammer' and is supported by a vast Baltic-Slavonic material. ${ }^{20}$

Second, and in my opinion more important: in connecting the Scandinavian kinn with rather dubious Slavonic 'hill' ( ${ }^{*} k i j$, i. e. ${ }^{*} k y j b$ or ${ }^{*} k \bar{u} j$ ) Melin ignores a very expressive detail of the landscape of the Old Russian town and the famous topographic legend about how Kiev had been founded.

I would like to call attention to the fact that one of the high places of ancient Kiev usually called "mountains" was long ago named Shchekovica/Shchekavica (Щековица / Щекавица, from the Russian shcheka (щека) which means 'cheek'). Most probably, this place-name was formed according to the same universal model of using anthropomorphic elements as did some Scandinavian geographic names. Generally speaking, the Russian words shcheka, shchjeki (щека, щеки) 'cheek, cheeks' traditionally have an additional meaning, which is now preserved in some dialects - 'steep, rocky bank of the river' ${ }^{21}$ It is quite possible that this meaning was reflected in another old Russian place-name, the name of the town Shchekarev in Volyn'. ${ }^{22}$

As for the Shchekovica in Kiev, it resembled one of the most important town centers during the Middle Ages. We have a story from the Hypatian Chronicle under 1182 where the monks of Kievo-Pecherskiy monastery unanimously decide to elect the priest of the church situated on Shchekovica their Father-Superior. ${ }^{23}$ No doubt, much more interesting for my etymological investigation is the famous "early"

103-110; IDEM, Miscellanea onomastica Rossica. I. Летопись Нестора как ономастический источник. II. Еще раз о Киеве, in: Восточнославянская ономастика: Материаль и исследования (Москва, 1979) 5-47.

(19) Seе: В. В. Иванов, В. Н. Торопов, Мифологические географические названия как источник для реконструкции этногенеза и древнейшей истории славян, in: Boпрось этногенеза и этнической истории славян и восточных романцеев: Методология и историография (Москва, 1976) 120.

(20) Sее: М. ФАсмеР, Этимологический словарь русского языка в четырех moмиаx, т. II (Москва, 1996) 230, 231.

(21) See, for example: Ibid., T. IV, 499.

(22) See: CCRC, vol. II, col. 737, 888.

(23) See: Ibid., col. 627. 
communication from the Tale of Bygone Years about the pre-Christian history of Kiev, in particular the death and burial of the Prince Oleg the Prophet. According the Chronicle he was buried on the "mountain" Shchekovica: "They bore him away and buried him upon the hill which is called Shchekovica. His tomb stands there to this day, and it is called the Tomb of Oleg." ${ }^{24}$ As it is well known, in the Novgorodian First Chronicle another version concerning the place of Oleg's tomb is contained. According to that source, he was buried not in Kiev but in Ladoga ${ }^{25}$ From the Chronicler's comments it is clear that for the epoch of both sources the time of Prince Oleg was the time of legends. However, it is possible that the location of his tomb was connected with the places that were associated with the zones and centers of the Varangian settlements in Rus'. In other words, Shchekovica as well suits the burial of the great Varangian as the traditionally "scandinavized" Ladoga (Aldeigjuborg in Old Norse sources).

Thus, the existence of the ancient place-name Shchekovica cannot but be connected with Melin's etymology of the Old Norse name of the town. Moreover, the presence of the appropriate Slavonic name drastically increases the likelihood that this very interpretation of the element $k ø n u-$ is the correct one rather than the alternatives. The identity of the two stems shchek- and kønu- alongside with the semantic transparency of the Slavonic element allows a more reliable judgment on the proper Scandinavian element.

Naturally, in this connection we must recollect the legend about Kiev's foundation contained in the Chronicle: "There were three brothers, Kii, Shchek, and Khoriv, and their sister was named Lybed'. ${ }^{26}$ Kii lived

(24) “...и погребоша и на горђ иже гл̈тьсА Щековица єсть же єго до сего дйи словєть могила Wлгова" (CCRC, vol. II, col. 29 s. a. 912).

(25) See: CCRC, vol. III, 109.

(26) In connection with the place-name Shchekovica, there is a very interesting etymological interpretation of the toponym Lybed' (Льъбедb) that refers it to the Slavonic *lüb- (cf. the Russian lybon' (Аьюбонь) 'the upper part of the head of an animal') reflected in the name of a part of the head ( ${ }^{*} l b b r, l o b[\lambda \circ \sigma]$ etc.) and rising ground in a landscape (a hill, cf. the Russian vzlóbok (взло́бок) etc.) (Иванов, ТороПов, Мифологические географические названия..., 123; cf.: ФАСмеР, Этилологический словарь русского языка..., т. II, 538-539, 507). Similar anthropological correlations in the Slavonic names of the Kiev landscape are very challenging, however, and they require some additional support, at least, such as would be provided by the existence of some other toponymic pairs or complexes using at once several names of the parts of the face, in the Slavonic material. 
upon the hill where the Borich trail now is, and Shchek dwelt upon the hill now named Shchekovica, while on the third resided Khoriv, after whom this hill is named Khorevitza. They built a town and named it Kiev after their oldest brother. Around the town lay a wood and a great pine forest in which they used to catch wild beasts. These men were wise and prudent; they were called Polianians, and there are Polianians descended from them living in Kiev to this day." ${ }^{27}$

Needless to say, the names of the legendary relatives are, as is usually the case in eponymic legends, derivatives of the place-names. However, another detail of the narration is more significant for us: originally all the three settlements are considered as almost equal, but the Chronicle perspective is such that in the foundation of the town the dominant settlement becomes that one which is connected with Kii's name. In other words, of the three "mountains" the main one becomes that single one for which the Chronicler has no other name than the proper name of its inhabitant, while Shchekovica and Khorivica turn into the elements of the city landscape, parts of a certain whole.

However, the Chronicler's view may not have been universal. In the epoch in question Kiev was "a small town" or, to be more exact, a number of settlements connected with each other but rather scattered about. The relative importance of these settlements may have changed over time or the Varangian view may simply have diverged from that of the Chronicler. At some stage Shchekovica could have been recognized as the town-forming and "name-giving" locus. We can only guess at the reasons why this may have happened. It cannot be excluded that Shchekovica was specially connected with places of Varangians living within the future Kiev; perhaps, they stayed there, for some reason, while sailing the Dnepr.

At any rate, from the viewpoint of etymology, the explanation allowing a connection of the Old Norse name of Kiev with the Old Sla-

(27) “И быша три братия: единому имя Кии, второму же имя Щекъ, третьему же имя Хоривъ, а сестра их Дыбедь. И съдяше Кыи на горь, идъже нынь увоз Боричевъ, и бъ с родомъ своимъ; а братъ его Щекъ на друзии горь, отъ него же прозвася Щековица; а третии Хоривъ, от него же прозвася Хоривица. И сотвориша градокъ, во имя брата своего старьишаго и наркоша имя Кыевъ. И бяше около ихъ льсъ и боръ велик, и бяху ловища звърие. И беша мужи мудри и смыслень, нарьчахуся Поляне, и до сего дне от них же суть кыянь; бяху же погань, жруще озером и кладязем и рощениемъ, якоже прочии погани" (CCRC, vol. III, col. 105; cf.: CCRC, vol. I, col. 9; vol. II, col. 7). 
vonic name of one of its districts seems very attractive. For the history of the Slavonic-Varangian relations, that would be first of all a striking example of the possibility of an adequate translation from one language to another in the early epoch. The translation appears to be the more successful, as it uses the semantic potential of the stems щекК- and kønu- in both languages, being not a morpheme cálque, but a translation of the meaning.

Moreover, it may be assumed that a certain sense gap between the place-names Kønugarðr and Shchekovica (Щековица) reflects certain changes in the reality and/or the recognition of those changes. Indeed, as it has been already mentioned, toponyms with -gardr in the Old Norse nomenclature of Eastern Europe directly correspond to the names of towns and cities, while, apparently, there is no such correspondence to the status of the settlement in the structure of the Slavonic name Shchekovica (Щековица). In other words, the thing signified was changing and thus the signifier, at least in the other language, was also changing: the Slavonic toponym was associated with a part of the landscape and the settlement found there, while the Scandinavian name was associated with the town growing in the place of the settlement.

Thus, paraphrasing the legend, one may assert that the future capital of Rus' was recognized as the town of Kii by the Slavs and as the town of Shchek by the Varangians. The sense of the word Kønugardr having a different nature from the Slavonic name Kiev (Кblєвъ) and being directly connected with another toponym, in my opinion, is the most logical development of the hypothesis by Elsa Melin. The idea advanced in her paper allows us to avoid the fruitless task of seeking a logical basis for the phonetic similarity of the toponyms Kiev (Kolז6r) and Kønugardr, a similarity which in any case is not very close. The supposition about the connection between the Scandinavian word Kønugardr and the Slavonic Shchekovica (Щековица) requires a minimum of reconstructive efforts to validate the etymological guess. Although later during the existence of the toponym Kønugarðr it could become close to the fixed and widely known place-name Kiev (Kolєвr) in different ways, nevertheless, this most likely occurred at the next stage of Slavonic-Varangian interrelations. This very process of "paronymic attraction" especially over the long and stable life of a toponym often conceals its primary origin, to the great discontent of etymologists. 


\section{SUMMARY}

One of the aspects of Slavic and Varangians language communication in Old Rus is the Vatangian toponym for Kiev - Kønugarðr. While in Scandinavian languages garðr was known to designate 'farmstead, estate, enclosure, yard', the origin and meaning of the first part of this place-name remains unclear. Following recent paper by the Swedish researcher Elsa Melin who in turn refers the element kønu- to the Old Norse noun kinn, originating from the Indo-European stem *genw- / genu- 'mouth; cheek; cheekbone', the author argues that the element kinn in case of Kønugardr is to be related not to 'a cheek' but 'a slope of the mountain' or 'a hill'. This corresponds to the universal linguistic tendency to transfer names of parts of the body and face to elements of landscape. For Melin's opinion, Scandinavian place-name containing the element kinn-is a cálque or, in any case, translation, of a certain Slavonic toponym, the author argues that kønu(<kinn-) goes back not to ${ }^{*}$ Kij-, as Melin assumes, but to ${ }^{*}$ Shchekovica / Shchekavica (Щековица / Щекавица, from the Russian shcheka [щека] 'cheek'), the name of one of the high places of ancient Kiev. The Russian words shche$k a$, shchjeki (щека, щеки) 'cheek, cheeks' traditionally have an additional meaning, which is now preserved in some dialects - 'steep, rocky bank of the river'. Thus, the existence of the ancient place-name Shchekovica cannot but be connected with Melin's etymology of the Old Norse name of the town. The identity of the two stems shchek- and kønu-alongside with the semantic transparency of the Slavonic element allows a more reliable judgment on the proper Scandinavian element. While Slavic place-name Kiev is related to Kij, one of four legendary persons who founded the town, the Scandinavian toponym for the very same place corresponds with Kij's brother Schek. Thus, paraphrasing the legend, one may assert that the future capital of Rus' was recognized as the town of Kii by the Slavs and as the town of Shchek by the Varangians. For the history of the SlavonicVarangian relations, that would be first of all a striking example of the possibility of an adequate translation from one language to another in the early epoch. The translation appears to be the more successful, as it uses the semantic potential of the stems ing not a morpheme cálque, but a translation of the meaning. 